\title{
A Fine-GRAINED ANALYSIS OF DIRECTOR DEPENDENCE: EXAMINING BOARD COMPOSITION IN DETAIL
}

\author{
Jonathan L. Johnson \\ \& \\ Alan E. Ellstrand \\ University of Arkansas \\ Fayetteville, AR \\ Catherine M. Dalton \\ $\boldsymbol{d}$ \\ Dan R. Dalton \\ Indiana University \\ Bloomington, IN
}

\begin{abstract}
Past corporate governance research that has incorporated the concept of directors' dependence on the CEO has operationalized dependence in numerous ways, often aggregating various indicators into a single construct. We extend this research with an examination of individual indicators of director dependence by partitioning director relationships into six categories. Relying on agency theory in combination with other organizational theories, we test hypotheses about relationships between the different categories of director dependence and the presence of antitakeover provisions and golden parachutes. We find that reciprocated interlocks are positively associated, and inside directors are negatively associated, with the presence of antitakeover provisions. Implications for theory, method. and practice are discussed.
\end{abstract}

\section{Introduction}

The relationships that corporate board members share with the CEO and/or the corporation itself have been of interest to researchers and governance activists for years. In both realms, the conventional wisdom holds that directors who are in some way dependent on the CEO are more likely to be derelict in their fiduciary duties to stockholders than wholly independent directors. Researchers, most of whom rely on agency theory, have formalized the argument and operationalized its constructs in myriad, but largely unsystematic, ways. Corporate governance activists agitate for independence, frequently by asking or demanding that directors with specific kinds of relationships with the CEO or the organization be precluded from serving on the board. Although these arguments are grounded in well-accepted theory, and activists have been quite successful in bringing about change, the empirical record on the consequences of board composition is mixed 
(e.g., Dalton, Daily, Ellstrand, \& Johnson, 1998; Westphal \& Milton, 2000; Zahra $\&$ Pearce, 1989). In this paper, we investigate one factor that may help account for the inconsistent findings across studies - alternative and potentially conflicting operationalizations of the director dependence construct.

The confusion associated with the conflicting operationalizations has theoretical, methodological and practical implications. The theoretical underpinnings vary for the different forms of director dependence on the CEO. For example, dependence that arises from directors who are related to the CEO is likely to be qualitatively different from that expected from directors who are also current officers. Different relationships may connote fundamentally different interests that are being represented on the board. Methodologically, the inconsistent operationalizations of the dependence construct across studies may account for the mixed empirical record, rendering tests of theory inconclusive in cases where the central construct is measured differently (Dalton, Daily, \& Johnson, 1999).

Practically, the need to disentangle the different forms of director dependence are important if for no other reason than that corporate governance activists, many of whom wield considerable market power, continue to agitate for the removal of several classes of directors. Institutional investors have become very willing to engage in publicized conflicts with the managers of specific firms in public and private forums (Serwer, 1996; Useem, 1993); activists publish books (e.g., Monks \& Minow, 1995) and distribute other materials that detail their recommendations for board composition (e.g., Minow \& Bingham, 1995); governmental agencies and stock exchanges impose reporting requirements to explicitly disclose the variety of potentially conflicting relationships (Daily \& Dalton, 1994); and the business press commonly publishes stories and commentary devoted to issues of corporate governance (e.g., Byrne, 1997; Colvin, 2001; Lavelle, 2001).

Thus, a more detailed examination of the kinds of relationships that exist between directors, the CEO, and the corporation itself may provide theoretical and practical insights for those interested in corporate governance. In this study, we examine the correspondence between six classes of director relationships and an outcome often associated with managerial expropriation of stockholder interests, the presence of antitakeover defenses.

\section{Theory and Hypotheses}

Managerialism and agency theory consider the board's primary role to be managerial oversight, although they differ in their predictions regarding the degree to which the board actually carries out this role. While managerialism suggests that the large majority of boards are in place to support the self-interested behavior of top executives, agency theory proposes that in the presence of efficient markets, directors will be forced to take their fiduciary responsibilities seriously and act in the best interests of shareholders (Bazerman \& Schoorman, 1983; Fama \& Jensen, 1983). Of the two perspectives, the recent literature favors agency theory (Johnson, Daily, \& Ellstrand, 1996; Zahra \& Pearce, 1989), primarily because it 
holds out the possibility for functional boards, which managerialism dismisses outright. Agency theory also provides a detailed theoretical framework for explaining circumstances under which directors can carry out their fiduciary responsibilities.

We rely on the most popular application of agency theory to corporate governance, which is built on a decision management model explained in detail by Fama and Jensen (1983). The model involves a four-step decision process. Professional managers are responsible for the decision management role - which includes the first (decision initiation) and third (decision implementation) steps - in which decision alternatives are created and developed, and if approved by the board, implemented. The board, as a fiduciary of the stockholders, is responsible for steps two (decision ratification) and four (monitoring), the decision control role, which involves reviewing and accepting or rejecting alternatives proposed by management and monitoring the implementation of approved decisions. The sine qua non of the model is the independence between the two classes of actors who are responsible for these roles. According to Fama and Jensen:

Without effective control procedures, such decision managers are more likely to take actions that deviate from the interests of residual claimants. An effective system for decision control implies, almost by definition, that the control (ratification and monitoring) of decisions is to some extent separate from the management (initiation and implementation) of decisions (1983: 304).

The model is predicated on the assumption of fundamental conflicts between managers' and directors' interests. According to the agency view of the firm, however, as long as the prescribed parties exclusively own the rights inherent in these roles, the governance of publicly held corporations will remain balanced. The theory further predicts that in competitive markets, only economically efficient complex corporations will survive. Because agency costs are nontrivial, the survivors will be governed by decision controllers and decision managers whose interests are independent excepting those formally prescribed by the model. When the independence between these two roles is violated, especially if the director is under the influence of the $\mathrm{CEO}$ in some way other than rational persuasion, the decision management process is unbalanced, agency costs will become excessive, and the firm will suffer in the financial and corporate control markets. There are a variety of ways that the prescribed independence between these roles may be violated, each of which has, in varying degrees, been the focus of past research and corporate governance activist concern.

Perhaps the most direct violation of the prescriptions from the decision management model occurs with the appointment of current officers of the corporation to the board. With such appointments, the decision management and decision control roles are not only linked, but united in the same person. The individuals who are responsible for developing and implementing corporate policy also ratify and 
monitor those decisions. For certain kinds of decisions, the conflicts of interest are clear enough that inside directors are precluded by some institutions - typically stock exchanges - from participating in certain roles, such as service on the audit or nominating committees or in determining top managers' salaries. No institution prohibits inside directors from advocating and voting on the adoption or rescission of antitakeover provisions, and certis paribus, each director may directly benefit from the job security that these policies provide. Many firms include insiders in addition to the CEO, each of whom may be intimidated into voting with the CEO who, as their boss, exercises considerable control over their professional positions.

Because of these potential conflicts of interest, the inside/outside director dichotomy is the most common operationalization of director dependence, although it is frequently combined into an aggregate variable with other indicators (cf, Dalton, et al., 1999). The insider variable has been used in several studies that relate to takeover activities. Singh and Harianto (1989), for example, found that the percentage of outside directors corresponded positively with the adoption of golden parachute contracts. Kosnik (1987) found that the proportion of outside directors was negatively associated with the payment of greenmail, although neither Davis (1991) nor Mallette and Fowler (1992) found a relationship between their operationalizations of director dependence and the adoption of poison pills. The outsider variable has also been studied in relation to market reactions to the adoption of antitakeover provisions (Brickley, Coles, \& Terry, 1994; Sundaramurthy, Mahoney, \& Mahoney, 1997). For example, Sundaramurthy, Mahoney and Mahoney found that greater outsider representation on the board increased negative market reactions to the adoption of antitakeover provisions, suggesting that investors may feel betrayed by outside directors who do not take their fiduciary responsibilities seriously.

While the existing literature reports conflicting findings concerning the relationship between the inside/outside director dichotomy and the adoption of antitakeover measures, consistent with agency theory we propose:

Hypothesis 1: The proportion of directors who are currently employed by the corporation will be positively assaciated with the presence of antitakeover provisions and golden parachutes.

The logic underlying the separation of decision management and decision control roles also applies to directors who are affiliated with firms that are involved in economic relationships with the focal corporation. Directors who represent banks, law firms, suppliers, or customers of the corporation hold dual allegiances, one as fiduciaries of the stockholders, the other as agents of their employer. Presumably, when the interests of both parties are in conflict, their allegiance will be to their employer who exercises more direct control over their individual interests as their primary source of income. Most researchers regard these directors as dependent on the assumption that the CEO has discretion over the contracts that the firm enters into, and could thus sever lucrative contracts with firms represented by an ob- 
stinate director (cf., Mizruchi, 1983). In the context of the decision management model, this kind of relationship gives the primary decision manager, the CEO, power over the decision controller, potentially compromising the role of vetoing questionable management proposals. Moreover, in the event of a hostile change of control, the relationship that exists between the firm represented by the director and the focal corporation may also be put in jeopardy, which may provide further motivation for the director to ratify proposals that fail to serve the shareholders' interests. These forms of relationship are regarded as suspect by any number of agencies, including the SEC (which requires such relationships to be reported in great detail), stock exchanges, and institutional activists (including the Council of Institutional Investors).

Hypothesis 2: The proportion of directors affiliated with banks, law firms, customers, or suppliers that have contracts with the corporation will be associated with the increased likelihood of the presence of antitakeover provisions and golden parachutes.

Not all research on director dependence has relied exclusively on economic or legalistic arguments. Business management is conducted in an arena in which both economic and social forces operate (Granovetter, 1985). As Davis has noted, theories of management that ignore the social context "are at best incomplete and at worst misguided" (1991: 584). Four kinds of frequently investigated director relationships rely at least in part on social explanations.

The first is the appointment of former officers of the corporation to the board. Several governance researchers have included former officers in their operationalizations of director dependence, including studies of the adoption of antitakeover measures (e.g., Cochran, Wood, \& Jones, 1985; Kosnik, 1987; Mallette \& Fowler, 1992), and virtually all governance activists include former employees in their identification of dependent directors (IRRC, 1994). The rationale for classifying former employees as dependent is less straightforward than that of inside or affiliated directors, but the underlying logic is often not explicated (for exceptions, see Baysinger \& Butler, 1985; O'Reilly, Main, \& Crystal, 1988; Wade, O'Reilly, \& Chandratat, 1990).

While the CEO has no direct influence over these directors' employment or economic interests outside of their membership on the board and perhaps the value of their stockholdings in the firm, there may be reasons to expect that a compromising relationship may exist between the CEO and former officers. A former officer of the corporation - who may well have served as CEO of that corporation - is likely to strongly identify with the current CEO and have a similar worldview (Westphal \& Milton, 2000; Westphal \& Zajac, 1995). In the case of a CEO who was selected from within the organization, the CEO and director will have had very similar experiences, having shared the same or similar jobs within the same corporation. The current CEO may have developed "recipe behavior" in which the executive models his/her current actions based on the beliefs and values 
of past organizational leaders (Castrogiovanni, Baliga \& Kidwell, 1992). In addition, a friendship or mentoring relationship may have formed between the former officer and the current CEO if they had previously worked together as officers of the corporation. Indeed, it is possible - even likely - that the former CEO (a former officer and current board member) was instrumental in the appointment of the current CEO. Such a relationship fits Coleman's (1990) profile of an "affine agency" relationship, in which one party internalizes the interests of the other. Even in the case of an external CEO, the parties may have shared similar experiences and have developed an affinity for each other. In either case, the director's identification with the CEO would lead the director to take on the CEO's interests, and the decision controller's independence of the decision manager is breached.

Hypothesis 3: The proportion of directors who are former employees of the corporation will be positively associated with the presence of antitakeover provisions and golden parachutes.

Two corporations occasionally exchange officers and directors; that is, an executive of each firm sits on the other's board (Kosnik, 1987; Vance, 1983). In reciprocated interlocks, the director/officers involved may exchange favors, creating an arrangement of "mutual deference and forbearance" (Kosnik, 1987: 170). The decision controller of one board is the decision manager of the other, and vice versa. In this case, explicit quid pro quo exchanges may arise that compromise the decision making safeguards on both boards. The nature of the relationship between the officers involved may go beyond simple social exchange, as well. Useem (1984) found evidence that the interlocking directorate led to the formation of social ties. Researchers working in Marxist traditions (e.g., Domhoff, 1979) have long assumed that social relationships exist between the CEO and many concurrent directors prior to their appointment to the board. With reciprocated interlocks, this is a near certainty, excepting the unlikely case that the two officers were appointed to each other's boards simultaneously. Such directors are likely to act as affine agents for one another. Kosnik (1987) examined reciprocated interlocks in her study of the payment of greenmail and found that they led to an increase in the likelihood of the payment of greenmail, and we expect that will generalize to other forms of antitakeover defenses. Thus, we would expect these directors to support the CEO in taking steps to defend his or her position with the firm.

Hypothesis 4: The proportion of directors who are involved in reciprocated interlocking directorships will be positively associated with the presence of antitakeover provisions and golden parachutes.

Social forces are most pronounced in the case of directors with kinship ties to managers. Directors who are related to management may have been appointed to the board specifically to provide support for the managers (Coleman, 1990; 
Kosnik, 1987). Such relations are very likely to involve identification between the director and officer, an identity based on family ties rather than homophily, and thus likely to be very strong. The agency theory decision control model is again violated if the director's (decision control) objectivity regarding management (decision management) proposals is compromised. Beyond personal relationships and individual loyalties, hostile takeovers are also likely to jeopardize the social status of controlling families, potentially pitting the director's individual interests against those of the stockholders at large. For these reasons, we expect that the presence of directors with kinship relations to favor policies that will thwart hostile takeover attempts.

Hypothesis 5: The proportion of directors with kinship relationships will be positively associated with the presence of antitakeover provisions and golden parachutes.

Directors who were appointed after the CEO's tenure began may also be dependent on the CEO (Wade et al., 1990; Boeker, 1992). Researchers incorporating this operationalization of director dependence have argued that CEOs generally exercise substantial influence in the selection of outside directors and will favor nominees who they know are sympathetic to their own views and desires. Many directors who are asked to serve on boards have prior social relationships with the CEO, as well (e.g., Domhoff, 1979; Westphal \& Zajac, 1997). The personal affiliation violates the assumption of independence between the decision making roles in agency theory. The lack of dependence may be further exacerbated if the director feels a sense of obligation to the CEO, insofar as the appointment to the board confers individual financial and social benefits (Useem, 1984; Wade et al., 1990). In this social exchange perspective, the director may feel obliged to return the favor at some point in the future by voting to ratify a proposal that favors the CEO. Wade et al. (1990), for example, found that the proportion of directors appointed during the current CEO's tenure (referred to as "loyal directors" in this study) was positively associated with the adoption of golden parachute contracts.

Hypothesis 6: The proportion of loyal directors will be positively associated with the presence of antitakeover provisions and golden parachutes.

\section{Methods and Analysis}

\section{Sample}

The sample consisted of 200 randomly selected Fortune 500 corporations. Data were collected on 2,310 individual directors from the sample firms' proxy statements in 1991. We selected 1991 as the sample year for our study as it was late in a period of significant hostile corporate takeover activity. As such, corporate takeover defenses were widely established, yet not ubiquitious among large, American corporations (Useem, 1993). Thus, our sample provided the substantial 
variance required to study our dependent measure, the adoption of anti-takeover provisions that protect managers from market discipline, an indicator of opportunism. Descriptive statistics and correlations are in Table 1.

\section{Dependent Variables}

Although subject to some debate, antitakeover provisions are regarded as valid indicators of managerial opportunism (e.g., Davis, 1991). Such provisions may be used at management's discretion in attempts to thwart hostile bidders, and the presence of an arsenal of antitakeover defenses suppresses the initiation of takeover activities (Rosenbaum, 1993). The antitakeover provisions included in the study were on the books in 1991, and included (the number of sample firms adopting each of the provisions is in parenthesis): anti-greenmail provisions (25), classified boards (118), cumulative voting with significant stockholders (33), dual class common stock (21), fair price provisions (73), limitations on stockholder meetings (89), non-confidential voting (29), poison pills (138), and requirement of a supermajority approval vote (40). A detailed description of each of these antitakeover provisions may be found in Rosenbaum (1993). Table 2 lists the number of antitakeover provisions adopted by firms in the sample.

Another takeover related corporate policy that may pit managers' interests against those of the stockholders, golden parachutes, was included in the study. Golden parachutes (GPs) are contracts between top officers and the corporation that provides the officers with substantial compensation packages in the event of a change in corporate control. Of the 200 firms in the sample, 120 had adopted a golden parachute by 1991. Data for antitakeover amendments and golden parachutes were collected from the Investor Responsibility Research Center's Corporate Takeover Defenses 1993 publication (Rosenbaum, 1993).

\section{Independent Variables}

Directors employed by the corporation during the sample period were coded as inside directors. Directors were coded as consultants if granted a personal consulting contract with the corporation. Directors affiliated with any supplier, client, bank, or law firm of the organization were classified as organizational contract directors. Outside directors employed by the corporation within the five previous years were coded as former officers. Kinship directors consisted of individuals related by blood or marriage to managers or directors. Directors involved in officer-director swaps were coded as reciprocated interlock directors. Outside directors were classified as loyal if appointed to the board after the current CEO's tenure began.

Each of the variables was expressed as a proportion of the entire board. While independent variables in regression models need not conform to any particular statistical distribution, nonlinear transformations may increase the power of the tests (Tabachnick \& Fidell, 1996). We used the most common transformation of data expressed as ratios (Cohen \& Cohen, 1983), the arcsine transformation $\left(=2 *\right.$ arcsine $\left[\right.$ ratio $\left.\left.^{1 / 2}\right]\right)$, for each of the proportional variables. 
Table 1

Correlations and Descriptive Statistics

\begin{tabular}{|c|c|c|c|c|c|c|c|c|c|c|c|c|c|c|c|}
\hline & & Mean & sd & 1 & 2 & 3 & 4 & 5 & 6 & 7 & 8 & 9 & 10 & 11 & 12 \\
\hline 1 & Number Provisions & 2.83 & 1.49 & & & & & & & & & & & & \\
\hline 2 & Number of Directors & 11.55 & 3.05 & 0.01 & & & & & & & & & & & \\
\hline 3 & Assets $(\log )$ & 14.63 & 1.41 & 0.09 & $0.49 * * *$ & & & & & & & & & & \\
\hline 4 & Institutional Holdings & 0.53 & 0.16 & $0.19^{* *}$ & -0.05 & 0.11 & & & & & & & & & \\
\hline 5 & Major Stockholdings & 0.21 & 0.22 & $-0.34^{* *}$ & -0.12 & $-0.29 * * *$ & ${ }^{*}-0.27 * *$ & & & & & & & & \\
\hline 6 & Director Equity & 0.03 & 0.10 & -0.06 & 0.06 & -0.05 & $-0.17^{*}$ & $0.25^{* *}$ & & & & & & & \\
\hline 7 & Dual Leadership & 0.79 & 0.41 & 0.10 & $0.16^{*}$ & $0.21^{* *}$ & 0.06 & -0.08 & -0.03 & & & & & & \\
\hline 8 & Current Insiders ${ }^{a}$ & 0.25 & 0.12 & $-0.23^{* *}$ & -0.01 & -0.07 & $-0.24^{* *}$ & -0.06 & -0.02 & 0.03 & & & & & \\
\hline 9 & Kinship Relations ${ }^{x}$ & 0.06 & 0.11 & $-0.18^{*}$ & 0.07 & -0.12 & $-0.26^{* *}$ & $0.20^{* *}$ & $0.38^{* *}$ & -0.12 & $0.23^{* *}$ & & & & \\
\hline 10 & Former Officers ${ }^{a}$ & 0.06 & 0.07 & -0.03 & 0.12 & 0.03 & -0.11 & 0.08 & 0.09 & 0.05 & 0.08 & $0.15^{*}$ & & & \\
\hline 11 & Organizational Contracts & 0.04 & 0.07 & -0.08 & 0.03 & -0.11 & 0.04 & 0.08 & $0.19^{* *}$ & 0.05 & 0.04 & 0.12 & -0.13 & & \\
\hline 12 & Reciprocated Interlocks ${ }^{a b}$ & 0.02 & 0.05 & 0.07 & $0.24^{* *}$ & $0.16^{*}$ & -0.06 & 0.07 & 0.09 & -0.02 & 0.02 & 0.11 & -0.06 & 0.05 & \\
\hline 13 & "Loyal" Directors" & 0.31 & 0.23 & 0.01 & 0.02 & -0.04 & -0.01 & 0.04 & -0.03 & $0.18^{*}$ & -0.13 & 0.00 & $-0.17^{*}$ & 0.10 & 0.14 \\
\hline
\end{tabular}

${ }^{3}$ Means and standard deviations are average proportions of directors in each category across all firms. Aresine transformations of proportions were used in the correlations.

${ }^{b}$ Note that in spite of the low average proportion for some of the Reciprocated Interlock variable, 41 of the 200 firms had at least one such director on the board in 1991.

${ }^{*} p<.05$

$* * p<.01$

$* * * p<.001$ 
Table 2

Firms' Adoption of Antitakeover Amendments

\begin{tabular}{ccc}
\hline $\begin{array}{c}\text { Number } \\
\text { Antitakeover } \\
\text { Provisions }\end{array}$ & Number of Firms & Proportion \\
\hline 0 & 9 & $4.5 \%$ \\
1 & 34 & $17.0 \%$ \\
2 & 41 & $20.5 \%$ \\
3 & 50 & $25.0 \%$ \\
4 & 39 & $19.5 \%$ \\
5 & 18 & $9.0 \%$ \\
6 & 9 & $4.5 \%$ \\
\hline
\end{tabular}

\section{Control Variables}

Firm size. Firm size may act as a de facto takeover defense due to the volume of capital that must be raised in order to tender an offer (Davis, 1991). Firm size was measured as the $\log$ of total assets. We used the log transformation of this variable to correct for the high degree of skewness in firm size, thus ensuring that the data were properly distributed.

Stock ownership concentration. Ownership concentration in corporations increases the power of shareholders and provides incentives for individual stockholders to act against managerial opportunism (Demsetz \& Lehn, 1985). The variable was expressed as the percentage of stock held by owners of at least five percent of the firm's stock. Data were collected from the firms' proxy statements.

Institutional Ownership. Institutional investors are often regarded by managers as fickle owners willing to dump large blocks of stock at a moment's notice (Useem, 1993). Managers of firms with large institutional stockholdings may be especially wary. Data were collected from the Compact D/SEC database (Compact Disclosure, 1991, 1992), and expressed as the percentage of stock held by institutional investors.

Director Equity. Directors' and stockholders' interests are aligned when the directors have significant stockholdings. Such directors will likely favor takeovers to earn the typical premiums. This variable was expressed as the percentage of stock held by all directors.

Number of Directors. All of the board variables share a common term, the board size denominator. We included this variable as the relative percentage of any director type may be an artifact of the size of the board. Board size is the total number of directors on the board.

\section{Analysis}

The analysis proceeded in two stages. In the first stage, the sum of antitakeover provisions adopted by each corporation, not including golden parachutes, 
was used as an index of management entrenchment. The index is distributed approximately normally with insignificant skewness $(1.48$, standard error $=.172)$ and kurtosis $(-.594$, standard error $=.342)$. The number of antitakeover defenses was regressed on the control variables and hypothesized variables in a multi-step ordinary least squares (OLS) regression. The first block contained control variables, followed by the introduction of a block containing all independent (board) variables of theoretical interest. Hypotheses were evaluated in terms of the significance of the additional variance explained and by the significance of individual path values in the regression model.

In the second stage, logistic regression models predicting only poison pills and golden parachutes were estimated. Poison pills are often singled out from other antitakeover provisions because they are typically adopted without stockholder approval. Golden parachutes were estimated separately because they also typically circumvent the proxy process, and because they are qualitatively different in terms of intent from the other antitakeover provisions. The logistic regressions were also conducted hierarchically in the same order as the OLS hierarchical regressions. Chi-square tests were conducted to determine if the variables accounted for significant additional variance. Path significance was determined using the ratio of the Wald statistic to the standard error of the coefficient, which translates to a z statistic (Tabachnick \& Fidell, 1996).

\section{Results}

Results from the OLS regression and two logistic regression models are shown in Tables 3 through 5. The first hypothesis predicted that the proportion of current inside directors would positively covary with the overall number of antitakeover amendments (Table 3), poison pills (Table 4), and golden parachutes (Table 5). The findings are contrary to expectations across all three models. The percentage of current insiders was significantly related with the number of antitakeover provisions adopted $\left(B=-1.32^{* * *}\right)$, the presence of poison pills $\left(B=-2.90^{* * *}\right)$, and the presence of golden parachutes $\left(B=-2.87^{* * x}\right)$, but opposite from the predicted direction. The presence of former officers of the corporation on the board of directors was predictive of the adoption of golden parachutes $\left(B=-1.13^{*}\right)$, but again, in the direction opposite from expected. Former officers were not significant in the other models.

The proportion of directors involved in reciprocated interlocks explained significant variance in the number of antitakeover provisions $\left(B=.77^{*}\right)$, and in the intended direction, providing partial support for hypothesis 4 . Interlocks were not predictive of the presence of poison pills or golden parachutes.

\section{Discussion}

The assumption, held by many researchers and practitioners alike, that directors who are not strictly independent of the CEO will capitulate to the CEO's in- 
Table 3

Hierarchical Linear Regression Predicting the Number of Antitakeover Provisions

\begin{tabular}{|c|c|c|}
\hline & Model 1 & Model 2 \\
\hline Constant & $\begin{array}{l}3.03^{* * *} \\
1.18\end{array}$ & $\begin{array}{l}5.81^{* * *} \\
1.34 \\
\end{array}$ \\
\hline Number of Directors & $\begin{array}{c}-0.01^{*} \\
0.04\end{array}$ & $\begin{array}{r}-0.02 \\
0.04\end{array}$ \\
\hline Assets (log) & $\begin{array}{r}-0.02 \\
0.09\end{array}$ & $\begin{array}{r}-0.09 \\
0.09\end{array}$ \\
\hline Institutional Holdings & $\begin{array}{l}0.96 \\
0.64\end{array}$ & $\begin{array}{l}0.35 \\
0.66\end{array}$ \\
\hline Major Stockholdings & $\begin{array}{r}-2.27 \\
0.51\end{array}$ & $\begin{array}{l}-2.60^{* * *} \\
0.51\end{array}$ \\
\hline Director Equity & $\begin{array}{l}0.62^{* * * *} \\
1.07\end{array}$ & $\begin{array}{l}0.86 \\
1.12 \\
\end{array}$ \\
\hline Dual Leadership & $\begin{array}{l}0.29 \\
0.25 \\
\end{array}$ & $\begin{array}{l}0.38 \\
0.25\end{array}$ \\
\hline Current Insiders ${ }^{\mathrm{a}}$ & & $\begin{array}{l}-1.32^{* * *} \\
0.38 \\
\end{array}$ \\
\hline Organizational Contracts ${ }^{9}$ & & $\begin{array}{r}-0.24 \\
0.30\end{array}$ \\
\hline Former Officers ${ }^{a}$ & & $\begin{array}{l}0.12 \\
0.28 \\
\end{array}$ \\
\hline Reciprocated Interlocks ${ }^{d}$ & & $\begin{array}{l}0.77^{*} \\
0.37\end{array}$ \\
\hline Kinship Relations" & & $\begin{array}{r}-0.24 \\
0.26\end{array}$ \\
\hline "Loyal" Directors" & & $\begin{array}{r}-0.08 \\
0.16\end{array}$ \\
\hline $\begin{array}{l}\mathrm{R}^{2} \\
\mathrm{~F} \text { Change }\end{array}$ & $\begin{array}{l}0.137 \\
5.09^{* * *}\end{array}$ & $\begin{array}{l}0.218 \\
3.245^{* *}\end{array}$ \\
\hline
\end{tabular}

Arcsine transformations of proportions

$* p<.05$

$* * p<.01$

$* * * p<.001$ 
Table 4

Hierarchical Logistic Regression Predicting the Presence of Poison Pill Amendments

\begin{tabular}{|c|c|c|}
\hline & Model 1 & Model 2 \\
\hline Constant & $\begin{array}{r}4.04^{*} \\
(1.98) \\
\end{array}$ & $\begin{array}{l}9.27^{* * *} \\
(2.58)\end{array}$ \\
\hline Number of Directors & $\begin{array}{l}-0.11 \\
(0.07)\end{array}$ & $\begin{array}{l}-0.11 \\
(0.08)\end{array}$ \\
\hline Assets $(\log )$ & $\begin{array}{l}-0.26 \\
(0.14) \\
\end{array}$ & $\begin{array}{l}-0.36^{*} \\
(0.16) \\
\end{array}$ \\
\hline Institutional Holdings & $\begin{array}{l}4.29^{* * *} \\
(1.18) \\
\end{array}$ & $\begin{array}{r}3.17^{*} \\
(1.26) \\
\end{array}$ \\
\hline Major Stockholdings & $\begin{array}{l}-3.19 * * * \\
(0.95)\end{array}$ & $\begin{array}{l}-4.05^{* * *} \\
(1.06)\end{array}$ \\
\hline Director Equity & $\begin{array}{l}-5.44 \\
(3.00) \\
\end{array}$ & $\begin{array}{l}-4.43 \\
(3.44) \\
\end{array}$ \\
\hline Dual Leadership & $\begin{array}{c}0.64 \\
(0.43) \\
\end{array}$ & $\begin{array}{c}0.85 \\
(0.48) \\
\end{array}$ \\
\hline Current Insiders ${ }^{\mathrm{a}}$ & & $\begin{array}{l}-2.90^{* * *} \\
(0.80)\end{array}$ \\
\hline Organizational Contracts ${ }^{3}$ & & $\begin{array}{l}-0.47 \\
(0.56) \\
\end{array}$ \\
\hline Former Officers ${ }^{a}$ & & $\begin{array}{l}-0.13 \\
(0.53) \\
\end{array}$ \\
\hline Reciprocated Interlocks ${ }^{\mathrm{a}}$ & & $\begin{array}{c}0.21 \\
(0.76) \\
\end{array}$ \\
\hline Kinship Relations ${ }^{a}$ & & $\begin{array}{l}-0.29 \\
(0.46) \\
\end{array}$ \\
\hline "Loyal" Directors" & & $\begin{array}{c}0.17 \\
(0.32) \\
\end{array}$ \\
\hline $\begin{array}{l}\text { Chi-Square } \\
\text { (df) } \\
\text { Cox \& Snell R }\end{array}$ & $\begin{array}{l}53.67 * * \\
(6) \\
0.235\end{array}$ & $\begin{array}{l}19.99^{* *} \\
(6) \\
0.308\end{array}$ \\
\hline
\end{tabular}

"Arcsine transformations of proportions

$* p<.05$

$* * p<.01$

$* * \mathrm{p}<.001$ 
Table 5

Hierarchical Logistic Regression Predicting the Presence of Golden Parachutes

\begin{tabular}{|c|c|c|}
\hline & Model 1 & Model 2 \\
\hline Constant & $\begin{array}{c}6.33^{* *} \\
(1.97) \\
\end{array}$ & $\begin{array}{l}13.09 * * * \\
(2,66)\end{array}$ \\
\hline Number of Directors & $\begin{array}{l}-0.03 \\
(0.06) \\
\end{array}$ & $\begin{array}{l}-0.01 \\
(0.07) \\
\end{array}$ \\
\hline Assets (log) & $\begin{array}{l}-0.46^{* *} \\
(0.14)\end{array}$ & $\begin{array}{l}-0.63^{* * *} \\
(0.16)\end{array}$ \\
\hline Institutional Holdings & $\begin{array}{c}1.85 \\
(1.02)\end{array}$ & $\begin{array}{c}0.29 \\
(1.20)\end{array}$ \\
\hline Major Stockholdings & $\begin{array}{l}-1.82^{*} \\
(0.81) \\
\end{array}$ & $\begin{array}{l}-2.31^{*} \\
(0.92) \\
\end{array}$ \\
\hline Director Equity & $\begin{array}{l}-3.41 \\
(2.29) \\
\end{array}$ & $\begin{array}{l}-1.61 \\
(2.52) \\
\end{array}$ \\
\hline Dual Leadership & $\begin{array}{r}0.87^{*} \\
(0.38) \\
\end{array}$ & $\begin{array}{l}1.27^{* *} \\
(0.45)\end{array}$ \\
\hline Current Insiders & & $\begin{array}{l}-2.87^{* * *} \\
(0.73)\end{array}$ \\
\hline Organizational Contracts" & & $\begin{array}{l}-0.64 \\
(0.52)\end{array}$ \\
\hline Former Officers ${ }^{a}$ & & $\begin{array}{l}-1.13^{*} \\
(0.49)\end{array}$ \\
\hline Reciprocated Interlocks & & $\begin{array}{l}-0.40 \\
(0.65) \\
\end{array}$ \\
\hline Kinship Relations ${ }^{a}$ & & $\begin{array}{l}-0.74 \\
(0.43) \\
\end{array}$ \\
\hline "Loyal" Directors" & & $\begin{array}{l}-0.24 \\
(0.30)\end{array}$ \\
\hline $\begin{array}{l}\text { Chi Square } \\
\text { (df) } \\
\text { Cox \& Snell R2 }\end{array}$ & $\begin{array}{l}30.93 * * * \\
6 \\
0.143\end{array}$ & $\begin{array}{l}33.62^{* * * *} \\
6 \\
.276\end{array}$ \\
\hline
\end{tabular}

${ }^{a}$ Arcsine transformations of proportions

$* p<.05$

$* * p<01$

$* * * p<.001$ 
terests and against those of the stockholders, was not strongly supported by these tests. In fact, the strongest pattern of relationships involved inside directors, and was contrary to expectations. In only one case was a hypothesized relationship found significant.

The hypotheses, grounded in the decision management model that undergirds agency theory, were largely disconfirmed. In explaining these predictive failures, one might first look to specific exceptions that are allowed by the theory. Fama and Jensen (1983) provide a rationale for one exception to the independence argument, allowing for a limited number of officers to serve on the board, although their interpretation is often ignored among empirically oriented governance researchers. Fama and Jensen argued that inside directors may play a functional role on the board insofar as they provide a conduit of information to outside directors that circumvents the $\mathrm{CEO}$ about the internal workings of the firm. Their argument assumes the presence of strong alternative monitoring mechanisms - including an efficient market for corporate control and the unrestricted alienability of stockholdings (both relevant to the dependent variables in this study) - and also assumes that the board will protect officer directors from sanctions by the CEO. Our findings are consonant with this view if the assumptions hold, especially so with respect to antitakeover provisions. Ocasio (1994) notes that while "inside board members are direct subordinates of the CEO... they are also potential rivals to the CEO's power" (p. 291). Insiders may oppose antitakeover defenses if they insulate the $\mathrm{CEO}$ from the discipline imposed by the market for corporate control and thereby decrease their opportunities for promotion.

A similar explanation may apply to the case of former officers, who were negatively associated with the presence of golden parachutes. As with inside directors, former officers will likely have firm specific knowledge that is useful in decision making in the corporation, and thus serve a functional role on the board. In other words, the presence of a former officer on the board is not an automatic signal of managerial expropriation. Moreover, the CEO is likely to have even less direct power over this kind of director than insiders, in which case the former officer has no personal interest in granting the CEO a golden parachute. It may be that the former officer's psychological attachment is to the corporation itself rather than to the current $\mathrm{CEO}$, and thus, because golden parachutes may encourage the $\mathrm{CEO}$ to approve a takeover, the director might oppose its approval.

Only in firms where one or more directors was engaged in a reciprocated interlock was there significant positive covariance with the presence of multiple antitakeover provisions, as predicted by agency theory. There is clearly an opportunity for collusion between the $\mathrm{CEO} /$ directors involved in officer-director swaps. For most of the other relationships included in this study, a credible argument can be made that they could justifiably be appointed to the board for reasons other than the entrenchment of the CEO. No such argument is apparent in this case.

Explaining the other results is more easily accomplished by reference to alternative governance theories. While agency theory provides an elegant mechanism for the governance of complex organizations, the functioning of most corporate 
boards is more complex than that implied in the decision management model. In reality, directors serve multiple roles, including not only their fiduciary obligations as emphasized in agency theory, but also providing information and advice to the $\mathrm{CEO}$, procuring critical resources, and enhancing organizational legitimacy (Pfeffer \& Salancik, 1978; Johnson et al., 1996; Zahra \& Pearce, 1989). The fulfillment of such roles will often involve the appointment of directors who may have the appearance of dependence on the CEO. A CEO who uses a board to facilitate access to scarce critical resources (Pfeffer \& Salancik, 1978), salient information (e.g., Useem, 1984), and expertise (Westphal \& Zajac, 1997) would be more indicative of a management acting to enhance, not expropriate, stockholders interests. This is in keeping with stewardship theory, which holds that CEOs are more likely to be stewards of corporations rather than mere self-interested economic agents (Donaldson \& Davis, 1991). As such, most would be inclined to act in shareholders' interests irrespective of the effectiveness of the board as a monitoring mechanism.

The view that directors who are in some way dependent on the CEO may also be beneficial to the firm, and thus its stockholders, does not fit neatly within the agency theory framework. Such directors are entangled in a complex of motivations, dependencies, and competing interests that extend beyond those of agency theory's clearly delineated principal and agent roles. One researcher has even suggested that directorships involving representatives of banks or suppliers may actually empower the director relative to the CEO, opposite from the more common interpretation (Mizruchi, 1983). Similarly, Westphal (1999) has shown that social ties between outside directors and the CEO may not only facilitate the advisory role of the board, but may actually contribute to more effective monitoring as well. In other words, it is wholly possible that directors who may in some way be dependent on or socially linked to the CEO may provide other benefits to the board that offset the loss in independence that may compromise the fiduciary role. It may even be that larger boards can accommodate a certain number of directorships oriented toward the resource dependence, legitimacy, and advisory roles without losing the capacity, as a board, to carry out the fiduciary role (Dalton, Daily, Johnson, \& Ellstrand, 1999).

Methodologically, the inconsistent results reported across the different variables corroborate the conclusions of Dalton, Daily, and Johnson (1999), who found that the multiple operationalizations of director dependence that are found in the literature may help to account for the mixed empirical findings in investigations of relationships between board composition and a variety of outcomes. This study demonstrates in more detail how distinct operationalizations of director dependence may lead to different results for dependent variables of interest. We would not suggest that one operationalization of board independence or another is invariably superior, but rather that research in the future should employ separate operationalizations based in theory relevant to each kind of relationship studied.

With this, we are recommending a more complex view of the board, one that considers multiple forms of relationships between directors and officers. This is in 
keeping with recent empirical findings (e.g., Westphal, 1999) and the suggestions of reviews (e.g., Johnson et al., 1996; Zahra \& Pearce, 1989) that have argued for multiple roles for the board. While less accurate than studies that directly measure the nature of the relationships that exist between the CEO and directors (e.g., Westphal, 1999), looking for indicators of different kinds relationships that can be gleaned from proxy materials and other publicly available information sources would be much less costly, and would enable researchers to examine all publicly traded firms.

Three limitations must be taken into consideration when interpreting these results. First, the degree to which antitakeover provisions represent an expropriation of stockholder interests is an open debate. Recent research has shown that certain antitakeover provisions may serve stockholders' interests as well as those of management (e.g., Brickley et al., 1994). Certain events (e.g., Eckbo, 1990), ownership structures (Agrawal \& Mandelker, 1990), or board attributes (Brickley et al., 1994) may attenuate negative stock market reactions to the adoption of antitakeover provisions, or even change the direction of the reaction (e.g., Brickley et al., 1994). On the other hand, negative abnormal returns have been associated with the adoption of antigreenmail provisions (Eckbo, 1990), classified-board amendments (Jarrell \& Poulsen, 1987), supermajority amendments (Agrawal \& Mandelker, 1990), cumulative voting amendments (Bhagat \& Brickley, 1984), and poison pills (e.g., Ryngaert, 1988). Although Comment and Schwert (1995) concluded that poison pills did not substantially deter the takeover wave of the 1980 s and 1990s, they did find that stock prices declined for most firms following the announcement of the adoption of such provisions. Given that stockholders view the individual antitakeover amendments negatively, we believe that a strong case can be made that an arsenal of provisions is evidence for opportunism. Managers armed with a host of takeover defenses are more likely to be more interested in entrenchment than increasing shareholder wealth.

Second, the current takeover market has changed in important ways from the time this data was collected (1991). The current market is less characterized by unwelcome bids, and such differences may limit the generalizability of these findings. Also, as noted above, Comment and Schwert (1995) concluded that the most infamous of the antitakeover amendments, poison pills, had no substantive effect on the wave of takeovers in the 1980s and early 1990s. Thus, while antitakeover provisions may have been a valid indicator of managerial opportunism in the context of the time of the study, the specific outcomes may be less clearly indicative of managerial opportunism in today's market than at the time of the study. Future studies should examine these propositions against other measures of managerial opportunism.

The cross-sectional design of this study is a third limitation. The design precludes making strong inferences with respect to causal direction. Moreover, we are measuring the existence of such provisions, not the adoption, per se. It could be argued that the adoption of the amendment constitutes the real expropriation. However, while the adoption event is clearly of interest, we also believe that the 
mere presence of such amendments may act against stockholder interests inasmuch as they may suppress the initiation of takeover activity, and in such case, they may be used at the discretion of management to thwart the attempt (Rosenbaum, 1993). Boards are free to rescind any of these provisions at any time. Nonetheless, these limitations leave open alternative explanations for our findings that must be taken into consideration and addressed in future research.

\section{Conclusion}

In this study, we partitioned director relationships into more precisely defined categories, based on economic and social influence theories, than have been used in past research. We found that different classes of director relationships had different implications. Practically, these findings may suggest that relationships between directors and firm managers are sufficiently complex that board governance prescriptions based largely on simple inside/outside director distinctions are underspecified. We would not, however, suggest that governance activists' efforts to improve corporate governance are invalid. On the contrary, the variety of relationships between board members and managers merits more attention, not less. Relationships such as reciprocated interlocks, for example, provide the opportunity for opportunism with few, if any, offsetting benefits. Most other relationships that have been considered suspect - including inside directors and representatives of interdependent organizations - may provide benefits to the organization and its stockholders that offset the dangers of interdependent directors in certain contexts.

Our results may underscore the complexity of manager-director relationships. Perhaps the dynamic milieu in which corporate managers operate is not well captured by any single theory of corporate governance. Boards of directors play a variety of roles in different theories of the board (e.g., Baysinger \& Butler, 1985; Mintzberg, 1983), and each of these accounts will view the relationships that exist among officers and directors on boards differently. It may be that some of those differences will be better understood by a finer-grained approach to director dependence.

\section{References}

Agrawal, A. \& Mandelker, G. N. (1990). Large shareholders and the monitoring of managers: The case of antitakeover charter amendments. Journal of Financial and Quantitative Analysis, 25, 143-161.

Baysinger, B. D., \& Butler, H. N. (1985). Corporate governance and the board of directors: Performance effects of changes in board composition. Journal of Law, Economics, and Organization, $1,101-124$.

Bazerman, M.H. and Schoorman, F.D. (1983) A limited rationality model of interlocking directorates, Academy of Management Review, 8, 206-217. 
Bhagat, S. \& Brickley, J. A. (1984). Cumulative voting: The value of minority shareholder voting rights. Journal of Law and Economics, 27, 339-365.

Boeker, W. (1992). Power and managerial dismissal: Scapegoating at the top. Administrative Science Quarterly, 37, 400-421.

Brickley, J. A., Coles, J. L., \& Terry, R. L. (1994). The board of directors and the enactment of poison pills. Journal of Financial Economics, 35, $371-390$.

Byrne, J. A. (1997). The best and worst boards. Business Week, December 8, pp. 90-98.

Castrogiovanni, G.J., Baliga, B.R, \& Kidwell, Jr., R.E. (1992). Curing sick businesses: Changing CEOs in turnaround efforts. Academy of Management Executive, 6, May, pp. 26-41.

Cochran, P. L., Wood, R. A., \& Jones, T. B. (1985). The composition of boards of directors and incidence of golden parachutes. Academy of Management Journal, 28, 664-671.

Cohen, J. \& Cohen, P. (1983). Applied multiple regression/correlation for the behavioral sciences, 2nd. ed. Hillsdale, New Jersey: Lawrence Erlbaum Associates, Inc.

Coleman, J. S. (1990). Foundations of social theory. Cambridge, Massachusetts: The Belknap Press of Harvard University Press.

Colvin, G. (2001). Value driven. Forbes, February 5, p. 46.

Comment, R. \& Schwert, G. W. (1995). Poison or placebo? Evidence on the deterrence and wealth effects of modern antitakeover measures. Journal of Financial Economics, $\underline{39}, 3-43$.

Compact Disclosure. (1991). Compact D/SEC. Bethesda, MD: Disclosure Incorporated.

Compact Disclosure. (1992). Compact D/SEC. Bethesda, MD: Disclosure Incorporated.

Daily, C. M. \& Dalton, D. R. (1994). Bankruptcy and corporate governance: The impact of board composition and structure. Academy of Management Journal, 37, 1603-1617.

Dalton, D. R., Daily, C. M., Ellstrand, A. E., \& Johnson, J. L. (1998). Meta-analytic reviews of board composition, leadership structure, and financial performance. Strategic Management Journal, 19, 269-290.

Dalton, D. R., Daily, C. M., \& Johnson, J. L. (1999). On the measurements of board composition: Poor consistency and a serious mismatch of theory and operationalization. Decision Sciences, 30, 83-106.

Dalton, D. R., Daily, C. M., Johnson, J. L., \& Ellstrand, A. E. (1999). Number of directors on the board and financial performance: A conceptual synthesis and meta-analysis. Academy of Management Journal, 42, 674-687. 
Davis, G. F. (1991). Agents without principles? The spread of the poison pill through the intercorporate network. Administrative Science Quarterly, 36, 583-613.

Demsetz, H. \& Lehn, K. (1985). The structure of corporate ownership: Causes and consequences. Journal of Political Economy, 93, 1155-1177.

Domhoff, G. W. (1979). The Powers That Be: Processes of Ruling Class Domination in America, New York: Random House.

Donaldson, L. \& Davis, J. (1991). Stewardship theory or agency theory: CEO governance and shareholder returns. Australian Journal of Management, 16, 49-64.

Eckbo, B. E. (1990). Valuation effects of greenmail provisions. Journal of Financial and Quantitative Analysis, 25, 491-505.

Fama, E. F. \& Jensen, M. C. (1983). Separation of ownership and control. Journal of Law \& Economics, 26, 301-325.

Granovetter, M. (1985). Economic action and social structure: The problem of embeddedness. American Journal of Sociology, 91, 481-510.

IRRC (Investor Responsibility Research Center) (1994). Background report on boards of directors. Washington, D.C.: Investor Responsibility Research Center.

Jarrell, G. A. \& Poulsen, A. B. (1987). Shark repellents and stock prices: The effects of antitakeover amendments since 1980. Journal of Financial Economics, 1, 127-168.

Johnson, J. L., Daily, C. M., \& Ellstrand, A. E. (1996). Boards of directors: A review and research agenda. Journal of Management, 22, 409-438.

Kosnik, R. D. (1987). Greenmail: A study of board performance in corporate governance. Administrative Science Quarterly, 32, 163-185.

Lavelle, L. (2001). Shh! You'll wake the board. Business Week, March 5, p. 92.

Mallette, P. \& Fowler, K. L. (1992). Effects of board composition and stock ownership on the adoption of "poison pills." Academy of Management Journal, 35, 1010-1035.

Minow, N. \& Bingham, K. (1995). The ideal board. In Corporate Governance (Eds. Monks, R. A. G. \& Minow, N.), Cambridge, Massachusetts: Blackwell Publishers: 496-501.

Mintzberg, H. (1983). Chapter 6: The board of directors. Power In and Around Organizations. Englewood Cliffs, NJ: Prentice-Hall.

Mizruchi, M. S. (1983). Who controls whom? An examination of the relation between management and boards of directors in large American corporations. Academy of Management Review, 8, 426-435. 
Monks, R. A. G. \& Minow, N. (1995). Corporate Governance. Cambridge, MA: Blackwell Business.

Ocasio, W. (1994). Political dynamics and the circulation of power: CEO succession in U.S. industrial corporations, 1960-1990. Administrative Science Quarterly, 39, 285-312.

O'Reilly, C. A., III, Main, B. G., \& Crystal, G. S. (1988). CEO Compensation as tournament and social comparison: A tale of two theories. Administrative Science Quarterly, $33,257-274$.

Pfeffer, J. \& Salancik, G. (1978). The External Control Of Organizations: A Resource Dependence Perspective. New York: Harper \& Row, Publishers, Inc.

Rosenbaum, V. K. (1993). Corporate Takeover Defenses 1993. Washington, DC: Investor Responsibility Research Center.

Ryngaert, M. (1988). The effect of poison pill securities on shareholder wealth. Journal of Financial Economics, 20, 377-417.

Serwer, A. E. (1996). Mr. Price is on the line, Fortune, 134, 70-88.

Singh, H. \& Harianto, F. (1989). Management-board relationships, takeover risk, and the adoption of golden parachutes. Academy of Management Journal, 32, 7-24.

Sundaramurthy, C., Mahoney, J. M., \& Mahoney J. T. (1997). Board structure, antitakeover provisions, and stockholder wealth. Strategic Management Journal, 18, 231 1-245.

Tabachnick, B. G. \& Fidell, L. S. (1996). Using Multivariate Statistics, Third Edition. New York: HarperCollins Publishers.

Useem, M. (1984). Inner Circle: Large Corporations and the Rise of Business Political Activity in the U.S. and U.K. Oxford: Oxford University Press.

Useem, M. (1993). Executive Defense: Shareholder Power and Corporate Reorganization. Cambridge: Harvard University Press.

Vance, S. C. (1983). Corporate Leadership: Boards, Directors, and Strategy. New York: McGraw-Hill Book Company.

Wade, J., O'Reilly, C. A., III, \& Chandratat I. (1990). Golden parachutes: CEOs and the exercise of social influence. Administrative Science Quarterly, 35, 587-603.

Westphal, J. D. (1999). Collaboration in the boardroom: Behavioral and performance consequences of $\mathrm{CE}$ )-board social ties. Academy of Management Journal, 42, 7-24.

Westphal, J. D. \& Milton, L. P. (2000). How experience and network ties affect the influence of demographic minorities on corporate boards. Administrative Science Quarterly, 45, 366-398. 
Westphal, J. D. \& Zajac, E. J. (1995). Who shall govern? CEO/Board power, demographic similarity, and new director selection. Administrative Science Quarterly, 40, 60-83.

Westphal, J. D. \& Zajac, E. J.(1997). Defections from the inner circle: Social exchange, reciprocity, and the diffusion of board independence in U.S. Corporations. Administrative Science Quarterly, 42, 161-183.

Zahra, S. A. \& Pearce, J. A., II (1989). Boards of directors and corporate financial performance: A review and integrative model. Journal of Management, 15, 291-334.

Catherine M. Dalton is the David H. Jacobs Chair of Strategic Management in the Kelley School of Business, Indiana University, She received her Ph.D. in strategic management from Indiana University. Her research interests include corporate governance, compensation, strategic leadership, and ownership structures.

Dan R. Dalton is the Harold A. Poling Chair of Strategic Management and director of the Institute for Corporate Governance in the Kelley School of Business, Indiana University. He received his Ph.D. from the University of California, Irvine. His corporate governance research focuses on option repricing, equity holdings, stock-based compensation, and initial public offerings.

Alan Ellstrand is the Director of MBA Programs and Associate Professor in the Sam M. Walton College of Business, University of Arkansas. He received his $\mathrm{Ph} . \mathrm{D}$. from Indiana University. His research interests include corporate governance, top management teams, and the influence of the national political system on business operations.

Jonathan L. Johnson is an Associate Professor in the Sam M. Walton College of Business, University of Arkansas. He received his Ph.D. from Indiana University. His research interests include corporate governance and social networks within and between firms. 